\title{
LONG-DISTANCE OBSIDIAN TRANSPORT IN PREHISTORIC NORTHEAST ASIA
}

\author{
Yaroslav V. Kuzmin \\ Institute of Geology and Mineralogy, Siberian Branch of the Russian Academy of Sciences, Novosibirsk 630090, Russia. \\ E-mail: kuzmin@fulbrightmail.org \\ Keywords: obsidian, prehistoric exchange, Palaeolithic, Neolithic, Palaeometal, Russian Far East, Japan, Korea, Northeast China
}

\begin{abstract}
A brief overview of recent obsidian source studies in Northeast Asia (Japan, Russian Far East, Korea, and Northeast China) is presented. Obsidian was a valuable commodity since the early Upper Palaeolithic (ca. 30,000-10,000 BP), and the length of distances between sources and utilisation sites at that time was up to 800 $\mathrm{km}$. In the Jomon period of Japan, several large exchange networks existed, with obsidian transportation up to 1000 $\mathrm{km}$ from source to sites, often across open waters. The use of multiple obsidian sources shows the complex nature of raw material acquisition and use in prehistory.
\end{abstract}

\section{INTRODUCTION}

During the last 20-30 years, significant progress has been achieved in the study of obsidian exchange patterns in Northeast Asia, including the Japanese Islands, Russian Far East, Korean Peninsula, and Northeast China (Manchuria). The majority of investigated sites belong to the Upper Palaeolithic and Neolithic in Russia and Northeast China, and to Upper Palaeolithic and Jomon periods in Japan. In later times, the role of obsidian as a raw material was less significant due to the introduction of metals (bronze and iron), though its use persisted in some areas of Northeast Asia (such as Kurile Islands and Kamchatka Peninsula).

The determination of the primary sources of obsidian and the presence of this raw material in prehistoric assemblages plays a vital role in understanding the patterns of prehistoric exchange and migrations (e.g. WilliamsThorpe 1995). In this overview, the current state of obsidian sourcing in Northeast Asia is presented, based on recent summaries (Kuzmin 2006, 2008, 2010) with incorporation of the latest data.

\section{MATERIALS AND METHODS}

Several geochemical analytical methods, primarily Energy Dispersive X-ray Fluorescence (EDXRF or PXRF) and Neutron Activation Analysis (NAA), and less commonly Proton-Induced X-ray Emission and Proton-Induced Gamma-ray Emission (PIXE and PIGME, respectively), were employed to retrieve data on the elemental composi- tion of obsidian from the Russian Far East and Korean Peninsula (e.g. Kuzmin et al. 2002a, 2002b; Kim et al. 2007; Doelman et al. 2008; Jia et al. 2010, see Table 1). The statistical processing of these results provides a high degree of precision (probability of at least 95\%) for determining the geochemical signature of primary obsidian sources in prehistoric stone assemblages (for details see: Glascock et al. 1998). The geochemical signature can be used to determine the location of the obsidian source that was used by ancient populations. A variety of analytical methods was used to study the geochemistry of Japanese obsidian sources and artefacts (e.g. Izuho and Hirose 2010; Tsutsumi 2010; Obata et al. 2010).

The importance of the NAA application to regions which were not previously studied for obsidian provenance is highlighted by the fact that it allows the detection of a large number of chemical elements (up to 28). This makes the determination of source groups, which are primary sources and associated artifacts, more secure compared to routine EDXRF and other methods (e.g., PIXEPIGME) that identify the content of only 10-14 elements. In the latter case, it may be impossible to distinguish some primary sources. This is the case with the Akaigawa and Tokachi-Mitsumata sources on Hokkaido Island (Japan) which were not originally discriminated by $\mathrm{T}$. Warashina using EDXRF (see Izuho and Hirose 2010:13-15) but later were separated by both NAA (Kuzmin et al. 2002b) and improved EDXRF (Hall and Kimura 2002).

In this review, only the southern part of the Russian Far East, including Primorye [Maritime] Province, Amur River basin, and Sakhalin Island, is considered. The northern part of the region, namely Kamchatka and the Kuril Islands, is not discussed due to size limitation. Relevant research in archaeological obsidian provenance of the northern Russian Far East can be found in recent summaries (Grebennikov et al. 2010; Kuzmin et al. 2008; Phillips 2010).

\section{RESULTS AND DISCUSSION}

Long-distance prehistoric exchange of obsidian in mainland Northeast Asia

The number of primary obsidian outcrops in the mainland Northeast Asia is relatively small; throughout the 20 years 
Table 1. Elemental composition of major obsidian sources in the southern Russian Far East measured by NAA (after Glascock et al. 2011; Kuzmin and Glascock 2007; Kuzmin et al. 2002a), in parts-per-million (ppm), unless otherwise indicated. Source abbreviations: BP - Basaltic Plateau; OP - Obluchie Plateau; PK - Paektusan; SAM - Samarga; S-A - Shirataki-A; S-B Shirataki-B; O-A - Oketo-A; O-B - Oketo-B.

\begin{tabular}{|c|c|c|c|c|c|c|c|c|}
\hline Element & $\mathrm{BP}$ & OP & PK $^{*}$ & SAM & S-A & S-B & O-A & O-B \\
\hline $\mathrm{Na}(\%)$ & $2.35 \pm 0.1$ & $2.84 \pm 0.05$ & $3.06 \pm 0.09$ & $2.92 \pm 0.10$ & $2.88 \pm 0.06$ & $2.95 \pm 0.05$ & $2.82 \pm 0.05$ & $3.25 \pm 0.04$ \\
\hline $\mathrm{Al}(\%)$ & $7.90 \pm 0.39$ & $7.92 \pm 0.28$ & - & $7.22 \pm 0.24$ & $6.75 \pm 0.26$ & $6.72 \pm 0.31$ & $6.49 \pm 0.23$ & $6.94 \pm 0.18$ \\
\hline $\mathrm{Cl}$ & $91 \pm 38$ & $75 \pm 26$ & $724 \pm 63$ & $349 \pm 29$ & $540 \pm 127$ & $532 \pm 95$ & $488 \pm 110$ & $449 \pm 130$ \\
\hline $\mathrm{K}(\%)$ & $0.41 \pm 0.14$ & $1.08 \pm 0.12$ & $4.17 \pm 0.29$ & $2.98 \pm 0.22$ & $3.73 \pm 0.13$ & $3.80 \pm 0.17$ & $3.58 \pm 0.17$ & $3.05 \pm 0.18$ \\
\hline Sc & $18.0 \pm 1.0$ & $11.8 \pm 0.6$ & $1.10 \pm 0.09$ & $2.82 \pm 0.05$ & $2.67 \pm 0.03$ & $2.94 \pm 0.05$ & $3.30 \pm 0.02$ & $3.33 \pm 0.10$ \\
\hline $\mathrm{Mn}$ & $1108 \pm 47$ & $967 \pm 17$ & $308 \pm 5$ & $525 \pm 4$ & $384 \pm 6$ & $451 \pm 9$ & $325 \pm 5$ & $385 \pm 3$ \\
\hline $\mathrm{Fe}(\%)$ & $7.22 \pm 0.24$ & $6.39 \pm 0.23$ & $1.08 \pm 0.01$ & $0.97 \pm 0.17$ & $0.80 \pm 0.01$ & $0.75 \pm 0.02$ & $0.73 \pm 0.00$ & $0.89 \pm 0.03$ \\
\hline Co & 37.7. \pm 1.3 & $30.8 \pm 0.7$ & $0.28 \pm 0.07$ & $1.39 \pm 0.03$ & $0.13 \pm 0.01$ & $0.08 \pm 0.01$ & $0.53 \pm 0.04$ & $0.47 \pm 0.01$ \\
\hline $\mathrm{Zn}$ & $126 \pm 21$ & $125 \pm 3$ & $85 \pm 18$ & $32 \pm 5$ & $39 \pm 4$ & $36 \pm 4$ & $26 \pm 2$ & $37 \pm 0$ \\
\hline $\mathrm{Rb}$ & $12 \pm 3$ & $29 \pm 3$ & $236 \pm 8$ & $102 \pm 2$ & $151 \pm 2$ & $175 \pm 2$ & $135 \pm 1$ & $99 \pm 3$ \\
\hline $\mathrm{Sr}$ & $392 \pm 93$ & $470 \pm 77$ & $28 \pm 6$ & $250 \pm 17$ & $28 \pm 4$ & - & $67 \pm 11$ & $79 \pm 37$ \\
\hline $\mathrm{Zr}$ & $97 \pm 20$ & $134 \pm 14$ & $252 \pm 11$ & $132 \pm 3$ & $90 \pm 8$ & $87 \pm 8$ & $116 \pm 2$ & $128 \pm 0$ \\
\hline Cs & $0.24 \pm 0.07$ & $0.37 \pm 0.06$ & $3.89 \pm 0.15$ & $4.73 \pm 0.09$ & $9.64 \pm 0.11$ & $11.89 \pm 0.16$ & $6.80 \pm 0.05$ & $5.34 \pm 0.07$ \\
\hline $\mathrm{Ba}$ & $122 \pm 29$ & $346 \pm 55$ & $106 \pm 35$ & $533 \pm 15$ & $856 \pm 7$ & $189 \pm 18$ & $994 \pm 14$ & $722 \pm 10$ \\
\hline La & $6.4 \pm 1.1$ & $18.1 \pm 0.7$ & 67.7. \pm 1.5 & $19.7 \pm 0.3$ & $20.1 \pm 0.3$ & $13.3 \pm 0.3$ & $22.1 \pm 0.3$ & $21.0 \pm 0.4$ \\
\hline $\mathrm{Ce}$ & $14.4 \pm 2.1$ & $36.4 \pm 0.7$ & $137 \pm 4$ & $36.9 \pm 0.7$ & $42.9 \pm 0.7$ & $31.5 \pm 0.6$ & $43.5 \pm 0.2$ & $41.8 \pm 0.2$ \\
\hline $\mathrm{Nd}$ & $9.0 \pm 2.0$ & $18.6 \pm 0.8$ & $49.1 \pm 5.4$ & $12.0 \pm 0.7$ & $15.9 \pm 1.2$ & $11.5 \pm 0.9$ & $13.2 \pm 0.8$ & $15.5 \pm 0.4$ \\
\hline $\mathrm{Sm}$ & $3.72 \pm 0.29$ & $5.13 \pm 0.24$ & $10.8 \pm 0.4$ & $2.46 \pm 0.05$ & $3.99 \pm 0.06$ & $3.83 \pm 0.08$ & $3.39 \pm 0.05$ & $3.24 \pm 0.06$ \\
\hline $\mathrm{Eu}$ & $1.47 \pm 0.07$ & $1.61 \pm 0.11$ & $0.28 \pm 0.06$ & $0.48 \pm 0.01$ & $0.28 \pm 0.01$ & $0.13 \pm 0.01$ & $0.37 \pm 0.01$ & $0.54 \pm 0.01$ \\
\hline $\mathrm{Tb}$ & $0.86 \pm 0.27$ & $0.64 \pm 0.05$ & $1.61 \pm 0.12$ & $0.31 \pm 0.01$ & $0.63 \pm 0.02$ & $0.72 \pm 0.04$ & $0.50 \pm 0.03$ & $0.50 \pm 0.04$ \\
\hline Dy & $3.86 \pm 0.40$ & $3.51 \pm 0.38$ & $10.2 \pm 0.8$ & $1.88 \pm 0.24$ & $4.39 \pm 0.25$ & $5.14 \pm 0.58$ & $3.38 \pm 0.23$ & $3.35 \pm 0.18$ \\
\hline $\mathrm{Yb}$ & $1.34 \pm 0.10$ & $1.14 \pm 0.10$ & $4.51 \pm 0.31$ & $1.43 \pm 0.06$ & $3.00 \pm 0.09$ & $3.66 \pm 0.17$ & $2.58 \pm 0.07$ & $2.64 \pm 0.10$ \\
\hline Lu & $0.26 \pm 0.05$ & $0.16 \pm 0.02$ & $0.73 \pm 0.06$ & $0.26 \pm 0.02$ & $0.46 \pm 0.02$ & $0.53 \pm 0.01$ & $0.42 \pm 0.01$ & $0.39 \pm 0.01$ \\
\hline $\mathrm{Hf}$ & $2.29 \pm 0.17$ & $3.46 \pm 0.33$ & $10.0 \pm 0.2$ & $3.45 \pm 0.05$ & $2.80 \pm 0.06$ & $2.72 \pm 0.10$ & $3.17 \pm 0.01$ & $3.66 \pm 0.13$ \\
\hline $\mathrm{Ta}$ & $0.29 \pm 0.08$ & $0.65 \pm 0.17$ & $6.75 \pm 0.41$ & $0.81 \pm 0.02$ & $0.54 \pm 0.01$ & $0.65 \pm 0.01$ & $0.57 \pm 0.02$ & $0.52 \pm 0.01$ \\
\hline Th & $0.77 \pm 0.19$ & $1.48 \pm 0.26$ & $27.5 \pm 0.8$ & $8.85 \pm 0.17$ & $11.10 \pm 0.1$ & $9.70 \pm 0.1$ & $11.9 \pm 0.1$ & $9.3 \pm 0.2$ \\
\hline
\end{tabular}

*Paektusan Volcano-1 group (Kuzmin et al. 2002a:510).

of research, three major sources were identified: Paektusan [Baitoushan] Volcano, Basaltic Plateau, and Obluchie Plateau (Figure 1). The Paektusan Volcano in the northern part of the Korean Peninsula is the most abundant archaeologically among them; its obsidian is distributed in prehistoric complexes over vast distances, up to $800 \mathrm{~km}$ in a straight line (Figure 2). The earliest sites with the Paektusan obsidian are dated to ca. 24,000-25,500 BP on the Korean Peninsula (Popov et al. 2005; Kim et al. 2007), ca. 11,800 BP in Primorye [Maritime] Province of the Russian Far East (Warashina et al. 1998; Kuzmin 2006), and ca. 10,000-15,000 BP (approximate age) in Manchuria (Jilin and Heilongjiang provinces in Northeast China) (Jia et al. 2010).

The second most abundant source of obsidian is the Basaltic Plateau in southern Primorye Province (Figure 3). Previously, it was known from archaeological contexts only in Primorye (e.g. Kuzmin et al. 2002a), but it was subsequently identified at some sites in the neighbouring Amur River basin (Glascock et al. 2011) and Manchuria (Jia et al. 2010). The age of the earliest sites where this obsidian was utilised is ca. 10,000-12,000 BP in Primorye, ca. 10,800 BP in the Amur River basin, and ca. 10,000-15,000 BP (estimated age) in Manchuria. The maximal distance between source and sites is roughly 550 $\mathrm{km}$ (Figure 3).

The third source of obsidian is the Obluchie Plateau in the middle course of the Amur River, Russia (Figure 3). Archaeological sites with this kind of volcanic glass are widely distributed in the Amur River basin, with a distance of up to $750 \mathrm{~km}$ from the source. The age of utilisation sites ranges from ca. 12,000 BP to ca. $2000 \mathrm{BP}$.

\section{Obsidian exchange networks in insular Northeast Asia}

The Japanese Islands are definitely the 'champion' in terms of obsidian provenance studies in Northeast Asia (see, for example, review: Habu 2004:221-224). Numerous obsidian sources were identified on Hokkaido, Honshu, and Kyushu islands. Large exchange networks existed in the Upper Palaeolithic and the Jomon on Honshu Island (e.g. Yamamoto 1990; Sato and Tsutsumi 2007; Tsutsumi 2010). Two regions in Japan with the widest distribution of obsidian from sources to utilisation sites are: 1) Hokkaido Island (e.g. Izuho and Sato 2007; Kuzmin and Glascock 2007); and 2) Kyushu Island (Obata et al. 2004; Kim et al. 2007).

Hokkaido Island has at least 21 sources of obsidian (Izuho and Sato 2007). Two of them, Shirataki and Oketo, 


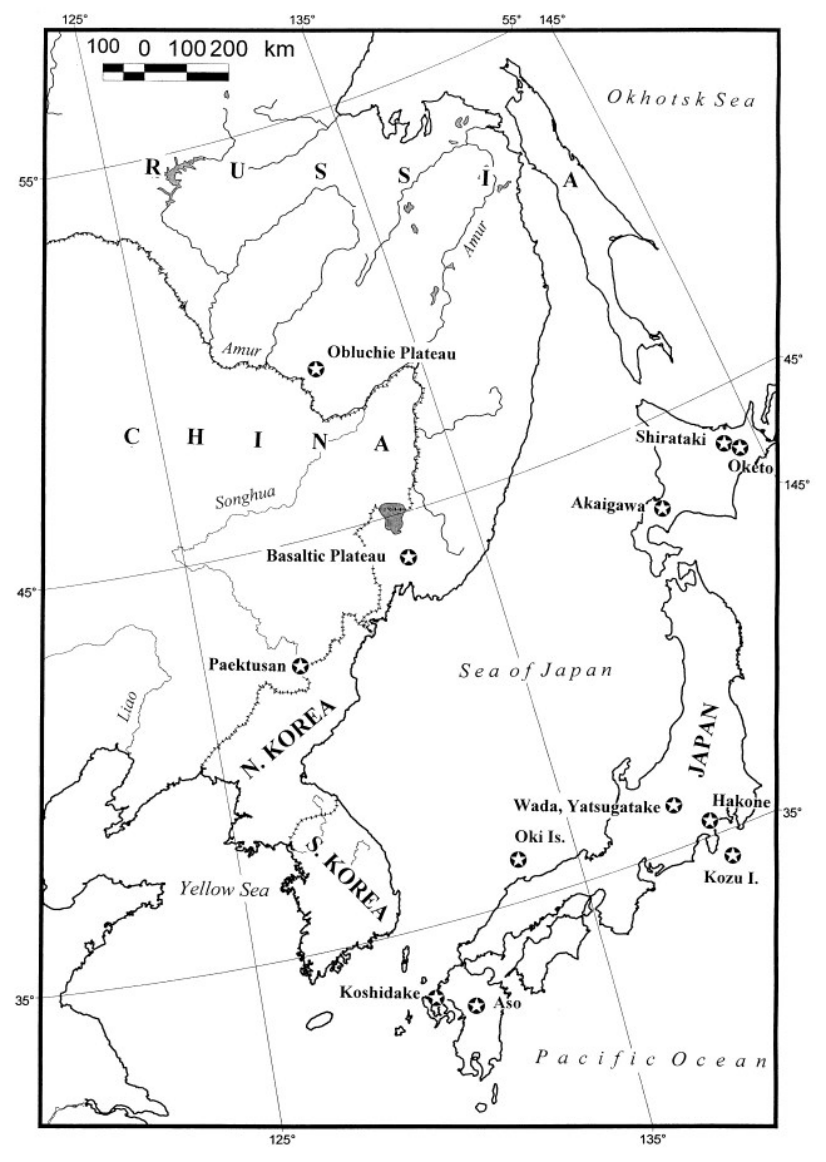

Figure. 1. Major obsidian sources in Northeast Asia (after Kuzmin 2006, 2010).

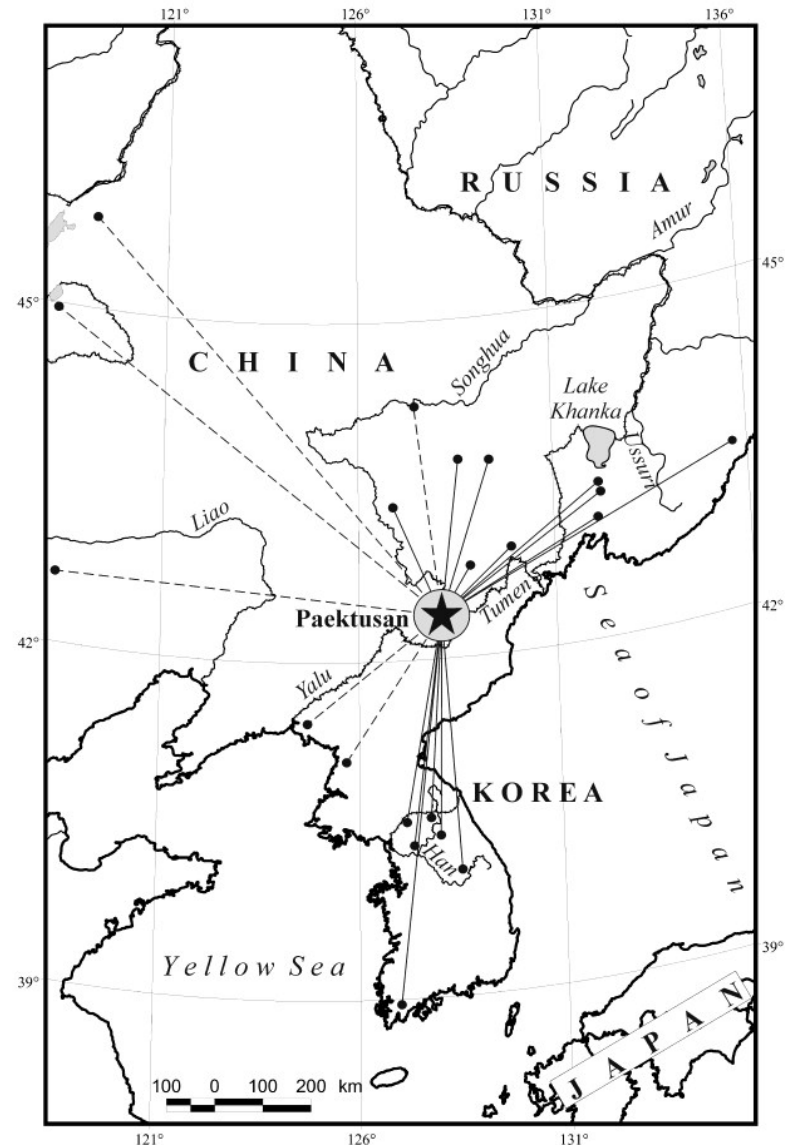

Figure. 2. The spread of obsidian in prehistory from the Paektusan source (after Kuzmin 2006, 2010; Kim et al. 2007; Jia et al. 2010). Solid lines show sites with the Paektusan obsidian confirmed by geochemical analyses; dashed lines show suggested spread of obsidian.

2007), a distance of ca. $350 \mathrm{~km}$ from the source (Figure 5 ). In later times, Kyushu obsidian (mainly from Koshidake source) was transported south to the Ryukyu Islands, beginning around $8000-6000 \mathrm{BP}$ and most extensively since ca. 4000 BP (Obata et al. 2004, 2010). At the end of the Jomon Period (ca. 2500 BP), the distances between source (Koshidake) and utilisation sites were up to 1000 $\mathrm{km}$ (Figure 5).

\section{Wider implications of obsidian exchange patterns in Northeast Asia}

The existence of large-scale obsidian exchange networks in the prehistory of Northeast Asia (Figs. 2-5) undoubtedly testifies to long-distance migrations or contacts in the Upper Palaeolithic and Neolithic, beginning at least at ca. 25,500 BP. This is primary information which should be taken into account by any serious prehistorian. Another important feature is the use of several obsidian sources at the same site in the Upper Palaeolithic and Neolithic of Primorye, Korean Peninsula, and in the Upper Palaeolithic and Jomon of the Japanese Islands (e.g. Kim et al. 2007; Kuzmin and Glascock 2007; Kuzmin et al. 2002a:513; Obata et al. 2010; Tsutsumi 2010). The use of several obsidian sources at the same site was also recently 


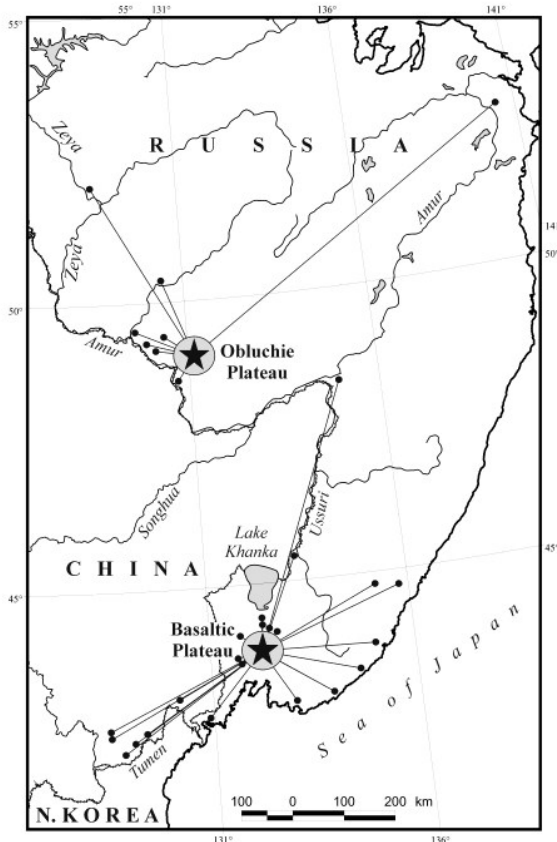

Figure. 3. The spread of obsidian from the Basaltic Plateau and Obluchie Plateau sources in prehistory (after Kuzmin 2006, 2010; Jia et al. 2010; Glascock et al. 2011).

served in the neighbouring territories of Manchuria (Jia et al. 2010) and the Kamchatka Peninsula (Kuzmin et al. 2008). Therefore, the strategy of acquisition of high quality raw material in prehistory appears to have been quite complex.

\section{CONCLUSIONS}

This brief review of the current data on obsidian transportation in prehistoric Northeast Asia shows that human contacts and/or migrations were very active from the early-middle Upper Palaeolithic (ca. 25,500 BP) onwards, with distances between sources and utilisation sites in the order of hundreds of kilometres. The range of obsidian spread in the Upper Palaeolithic in Northeast Asia was generally ca. $200-300 \mathrm{~km}$ and in some cases up to ca. 800 $\mathrm{km}$ (Paektusan Volcano source and related sites), and in the Neolithic (Jomon) up to ca. $1000 \mathrm{~km}$. It is clear that the obsidian provenance studies should continue in all parts of Northeast Asia with increasing pace. This gives us direct evidence of human movements and interactions.

\section{ACKNOWLEDGEMENTS}

This study was partly supported by several research and travel grants, mainly from Russian Foundation for Basic Sciences (RFFI) and Siberian Branch of the Russian Academy of Sciences (Project "GIS Modelling and Spatial Analysis of Environmental Systems and Their Components" of the Program IV.31.2; and Partnership Integrative Project No. 73); also from U.S. CRDF, NSF, and Fulbright Program; the Japan Foundation; and Korea Foundation. I am grateful to the IPPA Secretariat for financial aid in order to participate in the 19th Congress in Hanoi (Vietnam), November-December 2009. The core of this

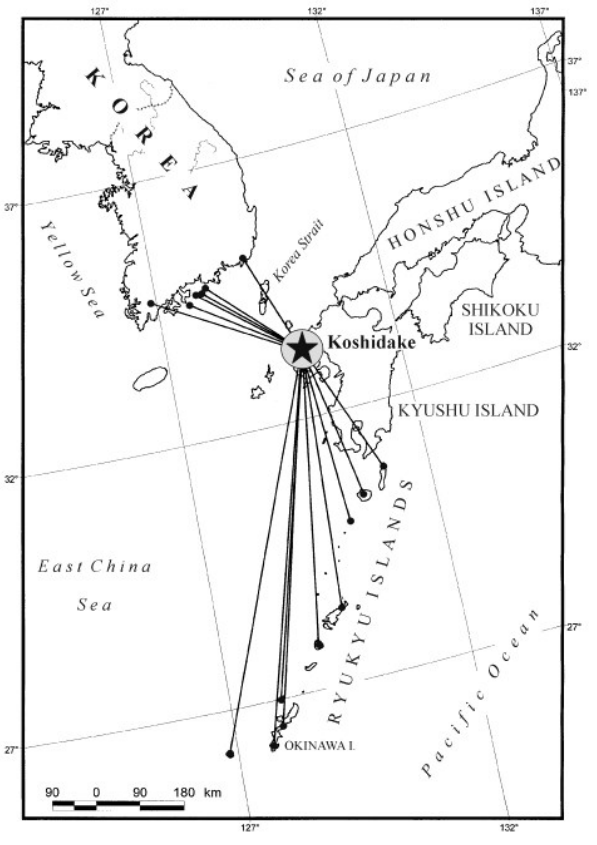

Figure. 5. The spread of obsidian from the Koshidake source in prehistory (after Obata et al. 2004; Kim et al. 2007).

; Phillips 2010; Glascock

paper was presented in Session B9 "Studies of Prehistoric Obsidian Sources in Northeast Asia: Recent Progress, Problems, and Research Trends" within the Scientific Programme of the 19th IPPA Congress. I am grateful to two anonymous reviewers for helpful suggestions on the earlier version of this paper.

\section{REFERENCES}

Doelman, T., R. Torrence, V. Popov, M. Ionescu, N. Kluyev, I. Sleptsov, I. Pantyukhina, P. White and M. Clements. 2008. Source selectivity: an assessment of volcanic glass sources in the southern Primorye region, Far East Russia. Geoarchaeology 23:243-273.

Glascock, M.D., G.E. Braswell and R.H. Cobean. 1998. A systematic approach to obsidian source characterization. In M.S. Shackley (ed.), Archaeological Obsidian Studies: Method and Theory, pp. 15-65. New York \& London: Plenum Press.

Glascock, M.D., Y.V. Kuzmin, A.V. Grebennikov, V.K. Popov, V.E. Medvedev, I.Y. Shewkomud and N.N. Zaitsev 2011. Obsidian provenance for prehistoric complexes in the Amur River basin (Russian Far East). Journal of Archaeological Science 38:1832-1841.

Grebennikov, A.V., V.K. Popov, M.D. Glascock, R.J. Speakman, Y.V. Kuzmin and A.V. Ptashinsky 2010. Obsidian provenance studies on Kamchatka Peninsula (Far Eastern Russia): 2003-9 results. In: Y.V. Kuzmin, M.D. Glascock (eds.), Crossing the Straits: Prehistoric Obsidian Exploitation in the North Pacific Rim, pp. 89-120. Oxford: Archaeopress.

Habu, Y. 2004. Ancient Jomon of Japan. Cambridge: Cambridge University Press. 
Hall, M. and H. Kimura. 2002. Quantitative EDXRF studies of obsidian sources in northern Hokkaido. Journal of Archaeological Science 29:259-266.

Izuho, M. and H. Sato. 2007. Retrospect and prospect of archaeological obsidian study on Hokkaido (Japan). Bulletin of the Indo-Pacific Prehistory Association 27:114-121.

Izuho, M. and W. Hirose. 2010. A review of archaeological obsidian studies on Hokkaido Island (Japan). In Y.V. Kuzmin, M.D. Glascock (eds.), Crossing the Straits: Prehistoric Obsidian Exploitation in the North Pacific Rim, pp. 9-25. Oxford: Archaeopress.

Jia, P.W., T. Doelman, C. Chen, H. Zhao, S. Lin, R. Torrence and M.D. Glascock. 2010. Moving sources: a preliminary study of volcanic glass artifact distributions in Northeast China using PXRF. Journal of Archaeological Science 37:1670-1677.

Kim, J.C., D.K. Kim, M. Yoon, C.C. Yun, G. Park, H.J. Woo, M.-Y. Hong and G.K. Lee. 2007. PIXE provenancing of obsidian artefacts from Paleolithic sites in Korea. Bulletin of the Indo-Pacific Prehistory Association 27:122-128.

Kuzmin, Y.V. 2006. Recent studies of obsidian exchange networks in prehistoric Northeast Asia. In D.E. Dumond, R.L. Bland (eds.), Archaeology in Northeast Asia: On the Pathway to Bering Strait (University of Oregon Anthropological Papers 65), pp. 61-71. Eugene, OR: University of Oregon.

Kuzmin, Y.V. 2008. Geoarchaeology of prehistoric cultural complexes in the Russian Far East: recent progress and problems. Bulletin of the Indo-Pacific Prehistory Association 28:3-10.

Kuzmin, Y.V. 2010. Crossing mountains, rivers, and straits: a review of the current evidence for prehistoric obsidian exchange in Northeast Asia. In Y.V. Kuzmin, M.D. Glascock (eds.), Crossing the Straits: Prehistoric Obsidian Source Exploitation in the North Pacific Rim, pp. 137153. Oxford: Archaeopress.

Kuzmin, Y.V. and M.D. Glascock. 2007. Two islands in the ocean: prehistoric obsidian exchange between Sakhalin and Hokkaido, Northeast Asia. Journal of Island and Coastal Archaeology 2:99-120.

Kuzmin, Y.V., M.D. Glascock and H. Sato. 2002b. Sources of archaeological obsidian on Sakhalin Island (Russian Far East). Journal of Archaeological Science 29:741-749.

Kuzmin, Y.V., V.K. Popov, M.D. Glascock and M.S. Shackley. 2002a. Sources of archaeological volcanic glass in the Primorye (Maritime) Province, Russian Far East. Archaeometry 44:505-515.

Kuzmin, Y. V., R.J. Speakman, M.D. Glascock, V.K. Popov, A.V. Grebennkov, M.A. Dikova and A.V. Ptashinsky. 2008. Obsidian use at the Ushki Lake complex, Kamchatka Peninsula (Northeastern Siberia): implications for terminal Pleistocene and early Holocene human migrations in Beringia. Journal of Archaeological Science 35:21792187.

Obata, H., I. Morimoto and S. Kakubuchi. 2004. Ryukyu Retto shutsudo no kokuyosekisei sekki no shutudo yoso ni tsuite [Sources of prehistoric obsidian tools in the Ryukyu Islands, Japan]. Sekki Gensanchi 4:101-136 (in Japanese).

Obata, H., I. Morimoto and S. Kakubuchi. 2010. Obsidian trade between sources on northwestern Kyushu Island and the Ryukyu Archipelago (Japan) during the Jomon period. In Y.V. Kuzmin, M.D. Glascock (eds.), Crossing the Straits: Prehistoric Obsidian Exploitation in the North Pacific Rim, pp. 57-71. Oxford: Archaeopress.

Phillips, S.C. 2010. Bridging the gap between two obsidian source areas in Northeast Asia: LA-ICP-MS analysis of obsidian artefacts from the Kurile Islands of the Russian Far East. In Y.V. Kuzmin, M.D. Glascock (eds.), Crossing the Straits: Prehistoric Obsidian Exploitation in the North Pacific Rim, pp. 121-136. Oxford: Archaeopress.

Popov, V.K., V.G. Sakhno, Y.V. Kuzmin, M.D. Glascock and B.-K. Choi. 2005. Geochemistry of volcanic glasses of the Paektusan Volcano. Doklady Earth Sciences 403:254259.

Sato, H. and T. Tsutsumi. 2007. The Japanese microblade industries: technology, raw material procurement, and adaptations. In Y.V. Kuzmin, S.G. Keates, C. Shen (eds.), Origin and Spread of Microblade Technology in Northern Asia and North America, pp. 53-78. Burnaby, B.C.: Archaeology Press.

Tsutsumi, T. 2010. Prehistoric procurement of obsidian from sources on Honshu Island (Japan). In Y.V. Kuzmin, M.D. Glascock (eds.), Crossing the Straits: Prehistoric Obsidian Exploitation in the North Pacific Rim, pp. 27-55. Oxford: Archaeopress.

Vasilevski, A.A., V.A. Grischenko and L.A. Orlova. 2010. Periods, boundaries, and contact zones in the Far Eastern insular world of the Neolithic (based on the radiocarbon chronology of sites on the Sakhalin and Kuril Islands). Archaeology, Ethnology \& Anthropology of Eurasia 38/1:10-25.

Warashina, T., H. Higashimura, H. Sato and Z. S. Lapshina. 1998. Sekki genzai no sanchi bunseki [Analysis of lithic artefact sources]. In Nihon Bunkazai Kagaku-kai (eds.), Nihon Bunkazai Kagaku-kai dai 15 kai Taikai Kenkyu Happyo Yoshi, pp. 138-139. Nara: Nihon Bunkazai Kagaku-kai (in Japanese).

Williams-Thorpe, O. 1995. Obsidian in the Mediterranean and Near East: a provenancing success story. Archaeometry 37:217-248.

Yamamoto, K. 1990. Space-time analysis of raw material utilization for stone implements of the Jomon culture in Japan. Antiquity 64:868-889. 